\title{
Hubungan Tingkat Kecemasan dengan Lama Kala I di Bidan Praktek Mandiri Belakang Pondok Kota Bengkulu
}

\author{
Riska Safitri ${ }^{1}$, Rafidaini Sazarni $\mathrm{R}^{2 *}$, Pawiliyah ${ }^{3}$ \\ 1. STIKES Tri Mandiri Sakti Bengkulu, Jl. Hibrida Raya No.3 Sido Mulyo, Kota Bengkulu, Indonesia, 38229 \\ 2*. STIKES Tri Mandiri Sakti Bengkulu, Jl. Hibrida Raya No.3 Sido Mulyo, Kota Bengkulu, Indonesia, 38229 \\ 3. STIKES Tri Mandiri Sakti Bengkulu, Jl. Hibrida Raya No.3 Sido Mulyo, Kota Bengkulu, Indonesia, 38229 \\ *e-mail: rafidainisazarni@gmail.com
}

(Received: 22-11-2019; Reviewed: 19-12-2019; Accepted: 27-12-2019)

\begin{abstract}
Anxiety is a normal condition that may be felt by every woman in dealing with labor process, but this condition causes psychiatric problems that inhibit labor process. The aims of this study was to determine relationship between level of anxiety with prolonged stage I on labor mother. The design of this study was cross sectional study. The sample in this study was all 30 primigravida mothers, using accidental sampling technique. The research instrument used questionnaires for anxiety levels and observation sheets for the length of labor. The data analysis technique was performed by the Exact Fisher's test. The results of this study showed there is a relationship between level of anxiety with prolonged stage I on labor mother primigravida $(p=0.001<0.05)$ with a close relationship category. It is expected that primigravida labor mothers will further increase the desire to find out about information so that with good knowledge will reduce the level of anxiety during labor process.
\end{abstract}

Keywords: Anxiety, Primigravida, Prologed Stage I

\begin{abstract}
Abstrak
Kecemasan merupakan suatu keadaan normal pada wanita dalam menghadapi proses persalinan, kondisi ini menyebabkan masalah yang menghambat kelancaran proses persalinan. Penelitian ini bertujuan untuk mempelajari hubungan antara tingkat kecemasan dengan lama kala 1 pada ibu bersalin. Desain penelitian ini dengan menggunakan studi cross sectional. Sampel dalam penelitian ini adalah seluruh ibu bersalin primigravida sejumlah 30 orang, dengan menggunakan teknik accidental sampling. Instrumen penelitian menggunakan kuesioner untuk tingkat kecemasan dan lembar observasi untuk lama persalinan. Teknik analisis data dilakukan dengan analisis univariat dan bivariat dengan uji Exact Fisher's. Hasil penelitian menunjukkan ada hubungan antara tingkat kecemasan pada ibu bersalin dengan lama kala 1 pada ibu primigravida $(\mathrm{p}=0,001<0,05)$ dengan kategori hubungan erat. Diharapkan kepada ibu bersalin primigravida lebih meningkatkan keinginan mencari tahu tentang informasi tentang proses persalinan, sehingga dengan pengetahuan yang baik akan mengurangi tingkat kecemasan saat menjalani proses persalinan.
\end{abstract}

Kata Kunci : Kecemasan, Lama Kala I, Primigravida 


\section{Pendahuluan}

Peristiwa yang berkesan bagi seorang ibu adalah proses kehamilan dan persalinan. Selama menjalani proes ini kecemasan dapat terjadi baik sebelum, selama, dan setelah kehamilan. Menurut World Health Organization (WHO) (2010), tingkat ansietas menjelang persalinan menjadi 13\% (Erawati, 2011). Distrres atau kecemasan ibu dapat menyebabkan terganggunya proses persalinan yang abnormal (Koelewijn, Sluijs, \& Vrijkotte, 2017).

Di Indonesia terdapat $107.000(28,7 \%)$ ibu hamil yang mengalami kecemasan dalam menghadapi persalinan (Mandagi, Pali \& Sinolungun, 2013). Pada penelitian yang dilakukan oleh Astria (2009) menunjukkan kecemasan lebih banyak dialami pada ibu hamil primigravida (kehamilan pertama) yaitu sebanyak 66,2 \%, dibandingkan dengan kecemasan pada ibu hamil multigravida sebanyak 42,2\% (Novitasari, Budiningsih, \& Mabruri, 2013).

Penyebab kecemasan pada persalina disebabkan karena ibu takut bayi lahir cacat, cemas sebagai akibat dari nyeri persalinan. Kurang pengetahuan tentang proses persalinan, dukungan dari lingkungan sosial (suami atau keluarga dan teman), tingkat pendidikan dan sosial ekonomi. Kecemasan ibu hamil dalam menghadapi persalinan dipengaruhi oleh beberapa faktor diantaranya yaitu; usia, tingkat pendidikan, faktor pengalaman (graviditas) dan pekerjaan (Hurlock, 2010).

Persalinan merupakan proses alamiah yang dialami seorang wanita. Asalkan kondisi fisik memadai tidak akan banyak mengalami kesulitan, namun tidak setiap wanita akan selalu siap menghadapi parsalinan karena persalinan disertai rasa nyeri dan pengeluaran darah. Ketidaksiapan akan menimbulkan rasa takut dan cemas pada ibu terutama pada wanita yang baru pertama kali melahirkan karena pada umumnya belum memiliki gambaran mengenai kejadian yang akan dialami pada akhir kehamilan terlebih pada persalinan. Kecemasan akan memobilisasi daya pertahanan individu. Cara individu mempertahankan diri terhadap kecemasan dapat dilihat dari gejala-gejala yang menentukan jenis gangguan (Maramis, 2005).

Penelitian yang dilakukan oleh Hayati, Herman, \& Agus (2017), bahwa hubungan tersebut menunjukkan ada hubungan antara tingkat kecemasan dengan lama persalinan dengan nilai $p<0,85$. Tingkat kecemasan ibu bersalin akan mempengaruhi lama persalinan, karena perasaan cemas yang dialami oleh ibu selama persalinan dapat merangsang hipotalamus sebagai pusat sistem limbik yang mengatur emosional. Hasil penelitian Fatikhah dan Setiyowati (2013), menunjukkan bahwa sebagian besar responden dengan tingkat kecemasan yang sedang sebanyak 18 (52,9\%) responden dan sebagian responden mengalami proses persalinan kala I yang cepat 22 (64,7\%) responden. Ada hubungan antara tingkat kecemasan dengan lama persalinan kala I didapatkan Fisher's Exact sebesar 15,415 dengan p value sebesar $0.000(\mathrm{p}=0,000<0.05)$.

Kecemasan pada ibu bersalin Kala I bisa berdampak meningkatnya sekresi adrenalin. Salah satu efek adrenalin adalah konstriksi pembuluh darah sehingga suplai oksigen ke janin menurun. Penurunan aliran darah juga menyebabkan melemahnya kontraksi rahim dan berakibat memanjangnya proses persalinan. Tidak hanya sekresi adrenalin yang meningkat tetapi sekresi ACTH (Adrenocorticotropic hormone) juga meningkat, menyebabkan peningkatan kadar kortisol serum dan gula darah. Kecemasan dapat timbul dari reaksi seseorang terhadap nyeri. Hal ini akan meningkatkan aktifitas saraf simpatik dan meningkatkan sekresi katekolamin. Sekresi katekolamin yang berlebihan akan menimbulkan penurunan aliran darah ke plasenta sehingga membatasi suplai oksigen serta penurunan efektifitas dari kontraksi uterus yang dapat memperlambat proses persalinan (Fatikhah, 2013).Persalinan lama berhubungan erat dengan peningkatan morbiditas pada ibu dan bayi, meningkatkan abnormalitas pada fisiologis persalinan dan peningkatan angka persalinan dengan seksio sesaria sedangkan pada bayi persalinan lama meningkatkan angka kematian bayi (Walsh, 2007).

Berdasarkan data rekam medik di Bidan Praktek Mandiri Belakang Pondok Kota Bengkulu masih banyak ditemukan keadaan partum lama karena persalinan kala I dan kala II. Tercatat dari bulan Januari-Desember 2017 sebanyak 562 dari seluruh kasus persalinan terdapat 360 kasus partus lama dari primigravida 401 persalinan multigravida.. Tujuan penelitian ini adalah untuk mengetahui apakah ada hubungan tingkat kecemasan dengan lama persalinan kala I pada ibu primigravida.

\section{Metode}

Penelitian ini dilakukan di Bidan Praktek Mandiri Belakang Pondok Kota Bengkulu pada bulan Mei-Agustus 2019. Rancangan penelitian menggunakan studi cross sectional. Populasi dalam penelitian ini adalah seluruh ibu primigravida dengan persalinan kala 1 yang bersalin di Bidan Praktek Mandiri Belakang Pondok Kota Bengkulu. Pengambilan sampel dilakukan pada penelitian ini adalah accidental sampling dengan jumlah sampel sebanyak 30 orang.

Teknik pengumpulan data dalam penelitian ini menggunakan data sekunder yang bersumber dari Bidan Praktek Mandiri Belakang Pondok Kota Bengkulu untuk mengukur partus lama, sedangkan data primer menggunakan lembar 
kuesioner tingkat kecemasan dengan membagikan kuesioner kepada responden. Teknik analisis data dilakukan dengan analisis univariat dan bivariat dengan uji Exact fisher's.

\section{Hasil}

1. Analisis Univariat

a. Usia

Tabel 1. Karakteristik usia pada ibu primigravida di bidan praktek mandiri belakang pondok kota bengkulu

\begin{tabular}{ccc}
\hline Usia & $\mathbf{n}$ & $\mathbf{\%}$ \\
\hline$<20$ Tahun & 1 & 0,3 \\
$20-35$ Tahun & 29 & 96,7 \\
\hline Jumlah & 30 & 100 \\
\hline
\end{tabular}

Tabel 1. Menunjukkan bahwa sebagian besar responden berusia 20-35 tahun dengan jumlah 96,7 \%.

b. Usia

Tabel 2. Karakteristik kecemasan pada ibu primigravida di bidan praktek mandiri belakang pondok kota bengkulu

\begin{tabular}{ccc}
\hline Kecemasan & $\mathbf{n}$ & $\boldsymbol{\%}$ \\
\hline Ringan & 8 & 26,7 \\
Sedang & 22 & 73,3 \\
\hline Jumlah & 30 & 100 \\
\hline
\end{tabular}

Tabel 2. Menunjukkan bahwa, tingkat kecemasan pada ibu primigravida sebagian besar yaitu 22 orang $(73,3 \%)$ dengan tingkat kecemasan sedang dan 8 orang $(26,7 \%)$ dengan tingkat kecemasan ringan.

c. Lama Kala I

Tabel 3. Karakteristik lama kala I pada ibu primigravida di bidan praktek mandiri belakang pondok kota bengkulu

\begin{tabular}{ccc}
\hline Lama Kala I & n & \% \\
\hline Tidak partus Lama & 11 & 36,7 \\
Partus Lama & 19 & 63,3 \\
\hline Jumlah & 30 & 100
\end{tabular}

Tabel 3. Menunjukkan bahwa Lama kala 1 pada ibu primigravida sebagian besar yaitu 19 orang $(63,3 \%)$ Partus Lama dan 11 orang $(36,7 \%)$ dengan tidak partus lama.

2. Analisis Bivariat

Analisis ini dilakukan untuk mengetahui hubungan antara tingkat kecemasan dengan lama kala 1 pada ibu bersalin primigravida di Bidan Praktek Mandiri Belakang Pondok Kota Bengkulu. Analisis diuji dengan menggunakan uji Exact Fisher'.

Tabel 4 Hubungan Tingkat Kecemasan Dengan Lama Kala 1 Pada Ibu Bersalin Primigravida Di Bidan Praktek Mandiri Belakang Pondok Kota Bengkulu

\begin{tabular}{|c|c|c|c|c|c|}
\hline \multirow[b]{2}{*}{ Tingkat kecemasan } & \multicolumn{2}{|c|}{ Lama kala 1} & \multirow[b]{2}{*}{ Total } & \multirow[b]{2}{*}{$\mathbf{P}$} & \multirow[b]{2}{*}{$\mathbf{C}$} \\
\hline & $\begin{array}{c}\text { Tidak partus } \\
\text { lama }\end{array}$ & Partus lama & & & \\
\hline Ringan & 7 & 1 & 8 & \multirow{3}{*}{0,001} & \multirow{3}{*}{537} \\
\hline Sedang & 4 & 18 & 22 & & \\
\hline Total & 11 & 19 & 30 & & \\
\hline
\end{tabular}

Berdasarkan tabel 4 terlihat bahwa dari 30 orang responden tingkat kecemasan pada ibu primigravida yang melahirkan Di Bidan Praktek Mandiri Belakang Pondok Kota Bengkulu terdapat 8 orang dengan tingkat kecemasan 
ringan dan 22 orang dengan tingkat kecemasan sedang. Dari 8 orang dengan tingkat kecemasan ringan terdapat 7 orang tidak partus lama dan 1 orang dengan partus lama. Dari 22 orang dengan lama kala 1 terdapat 18 orang partus lama dan 4 orang tidak partus lama.

Dari hasil uji Exact fisher's didapatkan p-value $=0,001<0,05$ artinya signifikan, maka Ho ditolak dan Ha diterima. Jadi ada hubungan antara tingkat kecemasan dengan lama kala 1 pada ibu bersalin primigravida di Bidan Praktek Mandiri Belakang Pondok Kota Bengkulu. Hasil uji Contingency Coefficient didapat nilai C=0,537 dengan p-value $=0,001<0,05$ berarti signifikan, nilai $C$ tersebut dibandingkan dengan $C_{\max }=0,707$, maka diperoleh nilai hasil perbandingan yaitu 0,76. Nilai ini terletak dalam interval 0,60-0,80 maka kategori hubungan erat.

\section{Pembahasan}

1. Tingkat Kecemasan Ibu Bersalin Primigravida

Hasil penelitian ini menggambarkan terdapat 22 orang $(73,3 \%)$ ibu bersalin primigravida dengan tingkat kecemasan sedang dan 8 orang $(26,7 \%)$ dengan tingkat kecemasan ringan. Hal ini terjadi karena pada ibu bersalin primigravida mengungkapkan bahwa mereka mengalami ketakutan dan kecemasan saat kala 1. Kekhawatiran mereka muncul dengan beraneka ragam, seperti takut tidak bisa melahirkan secara normal, takut bayinya lahir cacat, takut tidak bisa selamat, dan lain sebagainya. Ibu primigravida pada umumnya belum memiliki pengalaman dalam menjalani proses persalinan. Hasil ini didukung oleh pendapat Palupi (2014) yang mengungkapkan bahwa kecemasan dapat terjadi pada pengalaman baru, seperti kehamilan, kelahiran anak atau persalinan. Hal ini berarti bahwa kelompok ibu yang mengalami kehamilan baru pertama kali (primigravida) dan mengalami kecemasan yang lebih tinggi merupakan hal yang wajar dan biasa terjadi. Sedang bagi ibu yang menjalani kehamilan lebih dari satu kali (multigravida) dan mengalami kecemasan ringan juga merupakan hal yang wajar atau biasa terjadi.

Pada kehamilan pertama (primigravida) mayoritas ibu hamil tidak mengetahui berbagai cara mengatasi masalah dalam kehamilan sampai pada proses persalinan dengan lancar dan mudah, sehingga hal ini mempengaruhi kecemasan ibu hamil primigravida dalam mengahadapi persalinan. Didukung juga oleh pendapat Indrawati (2007) pada umumnya ibu primigravida mengalami kecemasan lebih tinggi dibandingkan dengan ibu multigravida dalam mengahadapi persalinan, disebabkan karena ibu baru pertama kali melahirkan.

Soewandi (1997) dalam Yogi (2010) mengatakan bahwa pengetahuan yang rendah mengakibatkan seseorang mudah mengalami stress. Ketidaktahuan terhadap suatu hal dianggap sebagai tekanan yang dapat mengakibatkan krisis dan dapat menimbulkan kecemasan. Stress dan kecemasan dapat terjadi pada individu dengan tingkat pengetahuan yang rendah, disebabkan karena kurangnya informasi yang diperoleh.

Faktor yang mempengaruhi dalam hal ini yaitu: usia, pendidikan, pengetahuan atau informasi, finansial, dukungan keluarga dalam hal ini adalah pendampingan saat persalinan, dan pengalaman (Masruroh, 2015). Menurut Isyah (2002) upaya untuk menanggulangi kecemasan istri pada trimester ketiga dampingan suami juga sangat berpengaruh terhadap kecemasan ibu. Terbukti dengan adanya dampingan suami yang diberikan pada calon ibu maka ibu merasa lebih tenang dan memiliki mental yang kuat untuk menghadapi persalinan (Syarul \& Shodiqoh, 2014).

2. Lama Kala 1 Pada Ibu Primigravida

Hasil penelitian menunjukkan bahwa terdapat 19 orang $(63,3 \%)$ ibu primigravida dengan partus lama, dan 11 orang $(36,7 \%)$ yang tidak partus lama. Hasil ini menunjukkan sebagian besar ibu mengalami partus lama. Partus lama dapat berkaitan dengan power, passage, passanger, psikologis, dan posisi ibu. Lamanya persalinan kala 1 merupakan waktu yang ditempuh dalam proses persalinan kala 1 pada primipara pase aktif berlangsung 12 jam sedangkan multipara berlangsung 8 jam atau dengan kata lain tidak melewati garis waspada pada patograf (Mulyati, 2016).

Penyebab terjadinya kala 1 lama dikarenakan ditemukan hambatan atau kendala. Kendala tersebut antara lain karena ibu merasa kelelahan saat meneran hal ini akan membuat perpanjangan waktu kala 1. Kondisi ini terjadi akibat tidak adekuatnya aliran darah ke utero plasenta dan lamanya janin dijalan lahir, faktor ketakutan, anatomi, ukuran uterus dan kontraktilitas uterus dikenal penentu lamanya persalinan (Halimatussakdiah, 2017). Sebab utama dari partus lama adalah disproporsi feto pelviks, malpresentasi dan malposisi serta kerja uterus yang tidak efisien, termasuk serviks yang kaku. Sementara partus lama dapat mengakibatkan pendarahan pada ibu inpartu maupun postpartum (Hayati, Herman \& Agus, 2017).

3. Hubungan Tingkat Kecemasan dengan Lama Kala 1 Pada Ibu Bersalin Primigravida di Bidan Praktek Mandiri Belakang Pondok Kota Bengkulu

Hasil penelitian menunjukkan bahwa dari 22 orang yang mengalami partus lama terdapat 18 orang dengan tingkat kecemasan sedang. Hal ini menunjukkan bahwa pada ibu primigravida belum memiliki pengalaman dalam 
proses persalinan, sehingga ibu berada pada respon stress dalam beradaptasi menghadapi proses persalinannya. Penelitian ini sejalan dengan pendapat Hayati, Herman \& Agus (2017), salah satu penyebab terjadinya partus lama adalah respon stress yang menempati urutan paling atas diantara lainnya. Kondisi ini terjadi karena ibu bersalin akan menghadapi berbagai masalah dalam adaptasinya selama proses persalinan, diantaranya rasa nyeri saat kontraksi, ketakutan akan ketidakmampuan dalam menangani masalah yang akan terjadi, ketegangan dan hiperventilasi. Faktor emosi atau psikologis terjadinya partus lama adalah ketakutan dan kecemasan ibu yang tidak teratasi selama melahirkan. Sebagian besar kejadian partus lama disebabkan karena kontraksi uterus yang tidak efisien sebagai respon terhadap kecemasan sehingga menghambat aktivitas uterus.

Kekhawatiran yang berlebihan bisa membuat otot-otot di jalan lahir berkerja berlawanan arah, karena dilawan oleh ibu yang kesakitan. Akibatnya, jalan lahir menyempit dan proses persalinan berjalan lebih lama dan sangat menyakitkan, bahkan bisa sampai terhenti. Kecemasan, ketakutan, kesendirian dan stress yang berlebihan dapat menyebabkan peningkatan jumlah hormon yang berhubungan dengan stress seperti kortiso dan epineprin. Hormon tersebut bekerja pada otot polos uterus. Peningkatan kadar hormon tersebut dapat menurunkan kontraksi uterus sehingga dapat menyebabkan persalinan yang lama (Hayati, Herman \& Agus, 2017).

Selain itu terdapat 4 orang dengan tingkat kecemasan sedang dan tidak partus lama. Hal ini dikarenakan memang ibu belum ada pengalaman bersalin, sehingga cenderung mengalami kecemasan, tetapi selama kehamilan dan ibu rutin melakukan senam hamil sehingga membantu kelancaran persalinan dan mendengarkan instruksi dari bidan untuk melakukan mobilisasi agar cepat dalam pembukaan. Olahraga juga akan menyalurkan tumpukkan stress secara positif, melakukan olahraga yang yang disarankan yang tidak memberatkan dan memberikan rasa nyaman seperti melakukan aktivitas agar otot-otot dasar panggul ikut bergerak. Pada latihan senam hamil terdapat teknik relaksasi yang dapat mengurangi kecemasan, saat individu mengalami ketegangan dan kecemasan yang bekerja adalah sistem saraf simpatetis, sedangkan saat rileks yang bekerja adalah sistem saraf para simpatis. Jika sistem saraf simpatis meningkatkan rangsangan atau memacu organ tubuh, memacu meningkatnya denyut jantung dan pernafasan, serta menimbulkan penyempitan pembuluh darah tepi (peripheral) dan pembesaran pembuluh darah pusat, maka sebaliknya sistem saraf parasimpatetis menstimulasi turunnya semua fungsi yang dinaikkan oleh sistem saraf simpatetis dan menaikkan semua fungsi yang diturunkan oleh sistem saraf simpatis. Maka relaksasi dapat menekan rasa tegang, cemas, senam hamil dan yoga juga dapat menurunkan tingkat kecemasan ibu bersalin primigravida (Solihah \& Warliana, 2019).

Selain itu terdapat 1 orang dengan tingkat kecemasan ringan yang mengalami partus lama. Pada saat penelitian responden ini terlihat menunjukkan bahwa ibu primigravida merasa lemas, lebih banyak tiduran/berbaring, tidak mau mobilisasi walaupun sudah diberikan motivasi untuk mobilisasi, selain itu kurangnya pengetahuan/informasi ibu tentang persalinan. Hasil penelitian ini sejalan dengan penelitian yang dilakukan Tahuru (2013), ibu bersalin primigravida yang tidak melakukan mobilisasi dikarenakan perasaan takut yang berlebihan terhadap persalinan yang akan dihadapi sehingga ibu tidak melakukan mobilisasi maka akan memperlambat proses persalinan.

Selain itu terdapat 7 orang dengan tingkat kecemasan ringan dan tidak partus lama. Hal ini dikarenakan sudah mendapatkan informasi tentang persalinan dan dengan adanya dukungan suami maka ibu akan merasa semakin rileks. Semakin rileksnya seseorang maka akan semakin mudahnya persalinan sehingga aliran darah dan hormon ibu akan semakin baik. Penelitian ini didukung oleh Kusumawati (2010) mengatakan bahwa pengetahuan yang rendah mengakibatkan lamanya persalinan lama kala 1 yang disebabkan kurang informasi yang diperoleh. Hal ini dapat mengurangi tingkat kecemasan seseorang dalam menghadapi persalinan.

Informasi akan meningkatkan pengetahuan seseorang dan pengetahuan akan meningkatkan kemampuan intelektual yang dapat meningkatkan kemampuan serta rasa percaya diri dalam menghadapi kecemasan yang akan mereka alami. Pengetahuan atau informasi merupakan fungsi penting untuk membantu mengurangi rasa cemas dan hal inilah yang menyebabkan mereka mengalami kecemasan ringan. Semakin banyak pengetahuan yang dimiliki seseorang akan mengetahui mekanisme yang akan digunakan untuk mengatasi kecemasannya (Masruroh, 2015).

Soewandi (1997) dalam Yogi (2010) mengatakan bahwa ketidaktahuan terhadap suatu hal dianggap sebagai tekanan yang dapat mengakibatkan krisis dan dapat menimbulkan kecemasan. Stress dan kecemasan dapat terjadi pada individu dengan tingkat pengetahuan yang rendah, disebabkan karena kurangnya informasi yang diperoleh. Sehingga dari pengetahuan tersebut merupakan suatu cara untuk memperoleh kebenaran pengetahuan, baik dari pengalaman diri sendiri maupun orang lain. Hal tersebut dilakukan dengan cara pengulangan kembali pengalaman yang diperoleh dalam memecahkan permasalahan yang dihadapi. Bila berhasil maka orang akan menggunakan cara tersebut dan bila gagal tidak akan mengulangi cara itu, oleh karena itu semakin tinggi kecemasannya maka lamanya kala I fase laten meningkat.

Menurut Solihah \& Warliana (2019) dukungan suami dapat menurunkan tingkat kecemasan saat persalinan pada ibu primigravida dalam menghadapi persalinan. Menurut Fatikha \& Setiyowati (2012), dukungan keluarga yang dapat diberikan suami antara lain membantu ibu beganti-ganti posisi, mengajak ibu bercerita, melakukan rangsangan taktil, memberikan makanan dan minuman. Membantu dalam mengatasi rasa nyeri, dengan memijat bagian 
lumbal/pinggang belakang dan memberikan kenyaman, perhatian serta menenangkan hati ibu dalam menghadapi dan menjalani proses persalinan, sehingga dapat membantu memperlancar persalinan.

Hasil uji Exact Fisher's diperoleh ada hubungan tingkat kecemasan dengan lama kala 1 pada ibu bersalin primigravida di Bidan Praktek Mandiri Belakang Pondok Kota Bengkulu. Hasil penelitian ini sejalan dengan penelitian Setyaningrum (2011) mengenai hubungan tingkat kecemasan ibu primigravida dengan kontraksi uterus kala I di RS Panti Wilasa Citarum Semarang pada 30 responden, ibu yang mengalami kecemasan dan memiliki kontraksi yang baik sebanyak 3,3\% sedangkan yang memiliki kontraksi tidak baik yaitu sebanyak $60 \%$. Ibu yang tidak mengalami kecemasan dan memiliki kontraksi yang tidak baik yaitu sebanyak 33,3\%, sedangkan yang memiliki kontraksi baik yaitu sebanyak 3,3\%. Hal ini membuktikan bahwa psikis ibu akan mempengaruhi proses persalinan. Jika tingkat kecemasannya rendah maka lama kala 1 akan semakin cepat atau sebaliknya jika tingkat kecemasannya semakin tinggi maka lama kala 1 semakin lambat/lama (Elisa, Wagiyo \& Primasnia, 2013).

Hasil uji Contingency Coefficient menunjukkan hubungan antara tingkat kecemasan dengan lama kala 1 pada ibu bersalin primigravida di Bidan Praktek Mandiri Belakang Pondok Kota Bengkulu kategori hubungannya erat. Hal ini menunjukkan bahwa tingkat kecemasan berpengaruh besar dalam terjadinya kala 1 lama pada ibu bersalin primigravida. Menurut pendapat Yogi (2016), untuk mengurangi kecemasan ibu diharapkan untuk mencari informasi serta menambah pengetahuannya tentang proses persalinan, sehingga dengan pengetahuan yang baik akan mengurangi tingkat kecemasan saat menjalani proses persalinan. Jika kecemasannya dapat diatasi maka semakin cepat proses pembukaan.

Peneliti menyarankan bagi ibu bersalin primigravida untuk mencegah lamanya persalinan lama kala 1 sering mengikuti kelas senam hamil, sering beraktivitas dan bergerak sehingga akan lebih cepat proses persalinan, mengkonsumsi makan-makanan yang bergizi, tidak stress dan sangat pentingnya peran suami dan keluarga dan upaya untuk mengurangi kecemasan antara lain memanfaatkan dukungan sosial, olaraga ringan, yoga dan relaksasi. Implikasi untuk perawat dan tenaga kesehatan lainnya untuk berperan aktif dalam memberikan motivasi tentang pendidikan dalam melancarkan proses persalinan, dan mengevaluasi kualitas pelayanan agar mencapai hasil yang diinginkan, banyak memberikan informasi tentang manfaat mobilisasi dan senam hamil untuk mengurangi kecemasan ibu bersalin.

Keterbatasan dalam penelitian ini adalah masih sedikitnya jumlah sampel dikarenakan hanya menggunakan satu lokasi penelitian yaitu satu tempat Bidan Praktik Mandiri, sehingga peneliti menganggap sampel belum sepenuhnya mewakili keadaan sebenarnya yang terkait dengan kecemasan dengan terjadinya kala 1 lama pada ibu bersalin terutama primigravida.

\section{Kesimpulan}

Berdasarkan hasil penelitian dapat disimpulkan bahwa terdapat hubungan antara tingkat kecemasan dengan lama kala 1 pada ibu bersalin primigravida di Bidan Praktek Mandiri Belakang Pondok Kota Bengkulu dengan katagori hubungan erat.

\section{Saran}

Bagi peneliti selanjutnya disarankan untuk mengembangkan penelitian dengan faktor lain yang berhubungan dengan lama kala I pada ibu bersalin, dan menggunakan metode yang berbeda serta perlu adanya penambahan jumlah sampel dalam penelitian dengan lingkup yang lebih luas. Bagi tenaga kesehatan

\section{Referensi}

Elisa, Wagiyo \& Primasnia, (2013). Hubungan Pendampingan Suami Dengan Tingkat kecemasan Ibu Primigravida Dalam Menghadapi Proses Persalinan Kala I Di Rumah Bersalin Kota Ungaran. Prosiding Konferensi Nasional Ppni Jawa Tengah 2013. Diakses dari: https://perawat18.blogspot.com/2012/12/hubunganpendampingan-suami-dengan.html

Erawati, Ambar Dewi, (2011). Buku Ajar Asuhan Kebidanan Persalinan Normal. Jakarta: EGC

Fatihatul, Hayati. B, Rahmatina. Herman. Agus, Meilinda, (2016). Perbedaan tingkat kecemasan ibu bersalin di puskesmas dengan di bidan praktik mandiri dan hubungannya dengan lama persalinan. 
Fatikhah, Ayu dan Setiyowati, Widyah. (2013). Hubungan Tingkat Kecemasan Dan Dukungan Keluarga Dengan Lama Persalinan Kala I Di BPM Ny Esti Wijayanti, AM.Keb Genuk. Semarang: Akademi Kebidanan Abdi Husada Semarang. Diakses dari: http://jurnal.akbidharapanmulya.com/index.php/delima/issue/view/2

Halimatussakdiah. (2007). Lamanya persalinan kala 1 dan II pada ibu multipara dengan APGAR score bayi baru lahir. Volume 2, Nomor $1 \mathrm{Hal}$; 7, Mei 2017.

Hurlock. (2010). Psikologi Perkembangan Suatu Pendekatan Sepanjang Rentang Kehidupan. Edisi Keenam. Jakarta; Erlangga.

Hayati, F., Herman, R. B., \& Agus, M. (2017). Perbedaan Tingkat Kecemasan Ibu Bersalin di Puskesmas dengan di Bidan Praktik Mandiri dan Hubungannya dengan Lama Persalinan. Jurnal Kesehatan Andalas, 6(3), 564-571.

Indrawati, (2007). Faktor-faktor yang mempengaruhi tingkat kcemasan pada ibu primigravida dalam menghadapi persalinan kala 1 di klinik bersalin mutiari kecamatan medan timur tahun 2007. Jurnal penelitian medan politeknik kemenkes negri medan. Diakses dari: https://karyatulisilmiah-skripsi.blogspot.com/2012/01/23faktor-faktor-yang-berhubungan.html

Koelewijn JM, Sluijs AM, Vrijkotte TGM, (2017). Possible relationship between general and pregnancy related anxiety during the first half of pregnancy and the birth process: a prospective cohort study. BMJ Open 2017;7:e013413. doi:10.1136/ bmjopen-2016-013413

Kusumawati, Estri. (2010). Hubungan penegetahuan primigravida tentang kehamilan dengan kecemasan dalam mengahadapi kemahilan trimester 1 di BPS fathona wn. jurnal ISSN 2087-502.

Magdagi DVV, Pali C, Sinolungan JSV. (2013). Perbedaan Tingkat Kecemasan Pada Primigravida Dan Multigravida Di RSIA Kasih Ibu Manado. Jurnal E-Biomedik ebm.1 (1); 61-67

Maramis. (2005). Diagnosis Gangguan Jiwa. Surabaya : Airlangga University Press.

Masruroh, N. (2015). Pengaruh Kecemasan Ibu Terhadap Proses Persalinan Kala 1 Fase Aktif di Bps Atik Suharijati $\begin{array}{llllllll}\text { Surabaya. Jurnal Ilmiah Keshatan } & \text { Vol. } & 8 & \text { No. } & \text { 2. Diakses dari: }\end{array}$ http://journal.unusa.ac.id/index.php/jhs/article/view/65

Mulyati, I. (2016). Hubungan asuhan sayang ibu dengan lamanya persalinan kala 1 dan II dipuskesmas Cikancung Tahun 2016. Diakses dari: http://repository.poltekkes-kdi.ac.id/513/1/skripsi.pdf

Novitasari, T., Budiningsih, T. E., \& Mabruri, M. I. (2013). Keefektifan Konseling Kelompok Pra-Persalinan untuk Menurunkan Tingkat Kecemasan Primigravida Menghadapi Persalinan. Journal Developmental and Clinical Psychology Universitas Negeri Semarang, 1(1), 21-27.

Palupi, H. F. (2014). Perbedaan Tingkat Kecemasan Ibu Primigravida Dengan Multigravida Dalam Menghadapi Proses Persalinan Kala I Di Rumah Bersalin Ngudi Saras Jaten Karanganyar. Jurnal Kesmadaska. Diakses dari: http://www.jurnal.stikeskusumahusada.ac.id/index.php/jk/issue/view/8

Syarul, F \& Shodiqoh R,E, (2014). Perbedaan Tingkat Kecemasan Dalam Menghadapi Persalinan Antara Primigravida Dan Multigravida. Jurnal Berkala Epidemiologi, Volume 2 Nomor 1, Januari 2014, Hlm. 141150. $\quad$ Diakses dari: https://www.academia.edu/35588621/perbedaan_tingkat_kecemasan_dalam_menghadapi_persalinan_antara_p rimigravida_dan_multigravida

Solihah \& Warliana, (2019). Determinan Yang Berhubungan Dengan Tingkat Kecemasan Ibu Bersalin Kala I Di Kabupaten Karawang. Jurnal Bidan “Midwife Journal” Volume 5 No. 01, Jan 2019. Diakses dari: http://jurnal.ibijabar.org/determinan-yang-berhubungan-dengan-tingkat-kecemasan-ibu-bersalin-kala-i-dikabupaten-karawang/

Walsh, (2007). Buku Ajar Asuhan Kebidanan Komunitas. Jakarta: EGC 
Yogi, Desi \& Etika. (2010). Hubungan Tingkat Kecemasan Ibu Bersalin Primigravida Dengan Lamanya Kala 1 Fase Laten Di Wilayah Kerja Puskesmas Sukosari Kecamatan Babadan Kabupaten Ponorogo 